\title{
Cell-mediated immunotherapy for hepatocellular carcinoma
}

\author{
Wei-Chen Lee \\ Division of Liver and Transplantation Surgery, Department of General Surgery, Chang-Gung Memorial Hospital, Chang-Gung University College of \\ Medicine, Taoyuan 333, Taiwan. \\ Correspondence to: Dr. Wei-Chen Lee, Division of Liver and Transplantation Surgery, Department of General Surgery, Chang-Gung Memorial \\ Hospital, Chang-Gung University College of Medicine, 5, Fu-Hsing Street, Kwei-Shan, Taoyuan 333, Taiwan. E-mail: weichen@cgmh.org.tw
}

How to cite this article: Lee WC. Cell-mediated immunotherapy for hepatocellular carcinoma. J Cancer Metastasis Treat 2017;3:244-9.

Article history:

Received: 27 Jul 2017

Accepted: 18 Oct 2017

Published: 31 Oct 2017

Key words:

Hepatocellular carcinoma,

dendritic cell,

immunotherapy

\begin{abstract}
Hepatocellular carcinoma (HCC) is the most common primary liver cancer. Most of the time, these tumors are diagnosed at late stages. Because no effective treatments exist for patients with advanced stage HCC, there is an urgent need for novel, effective treatments. Cancer cells originate as a consequence of abnormal expression of oncogenes or loss of tumor suppressor genes. Often, neoplastic transformation results in a hyper-mutated cellular genome, which in turn produces neo-antigens from mutated genes. These tumorspecific or tumor-associated antigens can be recognized by antigen-presenting cells and trigger T-lymphocytes to elicit anticancer immunity. Immune responses to cancers are often rendered ineffective by tumor immune-editing and immune-suppressive mechanisms. Yet, therapeutic strategies to stimulate anti-cancer immunity have had remarkable success in several solid and hematological malignancies. Among the various strategies for cancer immunotherapy, cell-mediated immunotherapy holds considerable promise to overcome anergy and systemic immune suppression. This brief review will focus on cell-mediated immunotherapy for HCC.
\end{abstract}

\section{INTRODUCTION}

Hepatocellular carcinoma $(\mathrm{HCC})$ is the sixth most common malignancy in the world ${ }^{[1]}$. The treatment modalities for HCC included liver transplantation ${ }^{[2,3]}$, liver resection ${ }^{[4]}$, local ablation ${ }^{[5]}$, transcatheter arterial chemoembolization (TACE) ${ }^{[6,7]}$, molecular target therapy ${ }^{[8,9]}$, radiotherapy ${ }^{[10]}$, chemotherapy ${ }^{[11]}$, and so on. According to Barcelona Clinic Liver Cancer (BCLC) classification, HCC can only be cured by liver transplantation, liver resection, and radiofrequency ablation (RFA) in the very early and early stages of the disease ${ }^{[12]}$. Even when tumors are completely removed by liver resection and liver transplantation, or by complete ablation by RFA, tumor recurrence is still not preventable. When tumors are in the intermediate stage, they can only be controlled by TACE. When tumors are in more advanced stages, patients can only be treated by molecular target therapy or supported by best care. There are as yet no effective treatments for

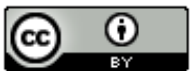

This is an open access article licensed under the terms of Creative Commons Attribution 4.0 International License (https://creativecommons.org/licenses/by/4.0/), which permits unrestricted use, distribution, and reproduction in any medium, as long as the original author is credited and the new creations are licensed under the identical terms.

For reprints contact: service@oaepublish.com

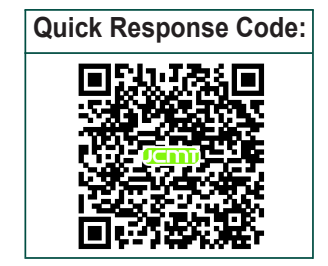


patients with advanced stage $\mathrm{HCC}$, so the search for effective treatments is a crucial one.

Cancer cells occur as a consequence of enhanced or aberrant expression of oncogenes or from loss of tumor suppressor genes. Cancer cells with genetic change will express new antigens ${ }^{[13]}$. These tumor-specific or tumor-associated antigens might be recognized by antigen-presenting cells and trigger T-lymphocytes to conduct anti-cancer immunity ${ }^{[14-16]}$. Immunotherapy has been studied as an attractive and novel therapeutic strategy to treat cancer since a few decades ago. This brief review will focus on cell-mediated immunotherapy for $\mathrm{HCC}$.

\section{IMMUNITY IN CANCER}

The immune system is the most important protection for a host in defending itself from foreign invaders and cancer development. As noted, cancer cells occur as a consequence of enhanced or aberrant expression of oncogenes or loss of tumor suppressor genes. The cancer cells with genetic change express new antigens and the new antigens may be captured and processed by dendritic cells (DCs) to trigger $\mathrm{T}$ cell-mediated immunity ${ }^{[17,18]}$.

Dendritic cells, the most potent and professional antigen-presenting cells, constitutively express major histocompatibility complex (MHC) class I and II and high levels of costimulatory molecules CD40, CD80, and CD86. When DCs meet antigens, they capture antigen, process it, and present the antigen to activate antigen-specific cytotoxic T-cells. Clinically, DCbased immunotherapy has been applied to treat endstage patients with B-cell lymphoma ${ }^{[19]}$, melanoma ${ }^{[20]}$, renal cell carcinoma ${ }^{[21]}$, prostate cancer ${ }^{[22]}$ and other tumors $^{[23]}$. The results are promising ${ }^{[24]}$. DC-based immunotherapy offers a hope of successful eradication of cancer [Figure 1].

However, DC-based immunotherapy yields only a $20 \%$ response rate in most of the clinical trials for advanced cancer diseases ${ }^{[25]}$. These results suggest that, even though DCs are the most powerful antigen-presenting cells, the immune system of most advanced cancer patients cannot be activated or may only be activated to a limited extent by DC. It is hoped that exploration of immunosuppressive mechanisms in tumor-bearing patients will improve the success of DC-based or cellmediated immunotherapy.

\section{IMMUNODEFICIENCY IN CANCER PATIENTS}

T-cells are the direct effector cells that attack and eradicate cancer cells. The cytotoxic ability of
Dendritic cells -- Cancer vaccine

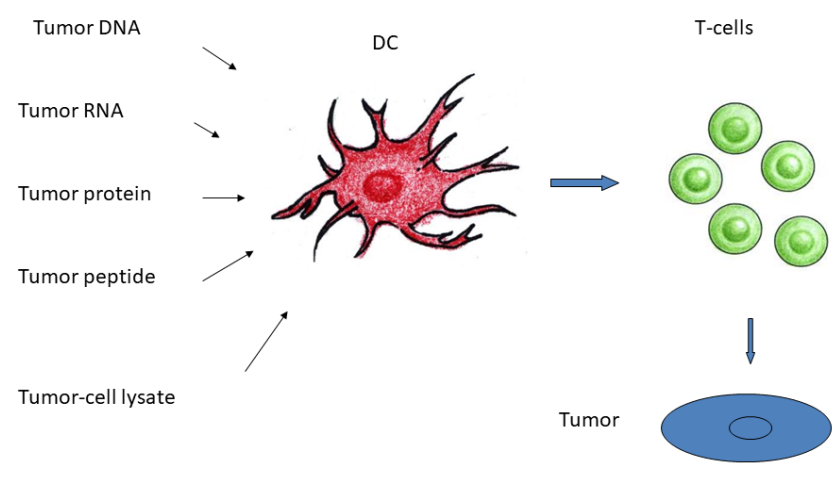

Figure 1: Dendritic cells can be pulsed by tumor DNA, RNA and proteins to activate antigen-specific T-cells. These activated T-cells can produce antigen-specific cytotoxicity to eradicate tumor cells

activated T-cells is directly related to efficacy of cancer treatment. In animal studies, tumor-infiltrating lymphocytes in tumor-bearing hosts have been proved anergic to cancer cells. Cancer cells may also induce $\mathrm{T}$-cell apoptosis or regulatory T-cells, which conduct peripheral tolerance to cancer cells ${ }^{[26,27]}$. Clinically, we have already observed that the percentage of lymphocytes decreases along with tumor growth in HCC patients ${ }^{[25]}$. In patients with significant numerous tumor mass, the percentage of lymphocytes is always below normal range. Immediately before patients die of HCC, lymphocytes cannot even be detected. Obviously, lymphocytes are suppressed by HCC through currently unidentified mechanisms.

Regulatory $T$ cells are immune suppressive cells ${ }^{[28]}$. In animal models, depletion of regulatory $T$ cells causes inflammatory colitis, and restoration of regulatory $T$ cells can prevent inflammatory colitis ${ }^{[29]}$. Therefore, natural regulatory $\mathrm{T}$ cells, $\mathrm{CD} 4^{+} \mathrm{CD} 25^{+} \mathrm{CD} 45 \mathrm{RB}$ low, are considered important cells in maintaining peripheral tolerance. Regulatory $T$ cells are also recognized as playing an important role in cancer diseases ${ }^{[30]}$. For gastric ${ }^{[31,32]}$, esophageal[ ${ }^{[33]}$, and other gastrointestinal malignancies, regulatory $T$ cells were increased in peripheral blood. For breast cancer, regulatory $T$ cells were increased in peripheral blood and in the tumor microenvironment ${ }^{[34]}$. For lung cancer, regulatory $T$ cells selectively inhibited host immune response and may have contributed to disease progression ${ }^{[35]}$. For $\mathrm{HCC}, \mathrm{CD} 4^{+} \mathrm{CD} 25^{+}$regulatory cells are also found in the tumor by immunohistochemical staining, and the number of regulatory $T$ cells is correlated to the prognosis. In our previous study, regulatory T-cells were identified in the tumor microenvironment. The number of regulatory T-cells was correlated to tumor size and contributed to prognosis. These regulatory $\mathrm{T}$ cells also appeared to suppress the DC-mediated 
immune responses ${ }^{[36]}$.

Regulatory T-cells are not the only immunosuppressive cells in hosts with cancer. In a murine cancer model, a group of cells expressing CD11b and Gr-1 in the spleen was noted when the cell population of spleen was analyzed. These cells are currently called myeloidderived suppressor cells (MDSC) ${ }^{[37]}$. Actually, MDSC are a population of cells of myeloid origin, including myeloid progenitors, immature macrophages, immature granulocytes, and immature dendritic cells. MDSC are characterized by production of reactive oxygen, nitrogen species, and arginase I to suppress immunity ${ }^{[38,39]}$. The CD11 $\mathrm{b}^{+} / \mathrm{Gr}-1^{+}$cells were expanded in mice bearing large tumors ${ }^{[40]}$. Deletion of $\mathrm{CD} 11 \mathrm{~b}^{+}$ $\mathrm{Gr}-1^{+}$cells in vitro or in vivo reverses the depression of CD8 ${ }^{+}$T-cell function.

Many researchers attempt to decrease or deplete MDSC to enhance cancer treatment ${ }^{[41-44]}$. Kusmartsev et al. ${ }^{[45]}$ implanted slow-releasing all-trans-retinoic acid subcutaneously in order to decrease MDSC from $27 \%$ to $11 \%$. De Santo et al. ${ }^{[46]}$ used nitro-aspirin, which released NO to interfere MDSC inhibitory enzymatic activity. Gemcitabine, amino-biphosphonase, and celecoxib all have been used to reduce the number of MDSC in order to enhance cancer treatment ${ }^{[47]}$. Moreover, all-trans-retinoic acid has been employed to treat renal cancer patients with metastasis, and there was a clinical response in 1 patient $(1 / 18)^{[48]}$. These data in animal models and a limited number of clinical trials implied that depletion or decrease of MDSC might be helpful in cancer treatment.

\section{CLINICAL CELL-MEDIATED IMMUNOTHERAPY FOR HCC}

\section{DC-based immunotherapy}

As mentioned, DCs are the most potent antigenpresenting cells. Theoretically, DCs can capture HCC-associated antigens, process the antigens, and activate antigen-specific T-cells to get rid of the tumors. However, the function of DCs is defective in advanced HCC, and antigen-specific T-cells cannot be activated properly. Therefore, DCs are cultured and matured ex vivo for immunotherapy.

In a phase I trial, Iwashita et al. ${ }^{[49]}$ enrolled 10 patients to receive autologous DC to treat unresectable HCC. DC was administered by injection into inguinal lymph nodes. Seven of 10 patients experienced delayed-type hypersensitivity response and one patient had tumor response. It was concluded that $\mathrm{DC}$ administered was safe and no major toxic effects were found. In another study, Palmer et al. ${ }^{[50]}$ used autologous DC pulsed with liver tumor cell line lysate (Hep G2) to treat 35 patients with advanced HCC. Twenty-five patients who received at least 3 courses of DC infusion were assessed for tumor response. Disease control rate was 28\%. Qiu et al..51] conducted a phase II clinical trial using $\alpha-1,3-$ galactosyl epitopes pulsed DC to treat stage III HCC patients. They enrolled 9 patients to have DC vaccination and 9 patients as control. The results showed that all patients had delayed hypersensitivity. Three of the 9 patients with DC vaccination had partial response. Compared to control, mean survival was prolonged from 10.1 to 17.1 months $^{[51]}$. In our previous study, DC progenitors from peripheral blood monocytes (PBMC) were cultured in granulocytemacrophage colony-stimulating factor (GM-CSF) and interleukin (IL)-4, pulsed with autologous tumor lysates and maturated by cytokine cocktail (tumor necrosis factor- $\alpha, \mathrm{IL}-1, \mathrm{IL}-6$ and PGE2). These DCs were positive for CD83 and expressed high levels of CD40, CD80, CD86 and HLA-DR. In in-vitro study, these DCs could activate T-cells. These ex-vivo prepared DCs were applied intravenously to treat 31 patients with advanced HCC. Among 31 patients, 4 (12.9\%) patients had partial response and 17 (54.8\%) patients had stable diseases. Disease control rate was $67.7 \%$. Compared to the same stage patients without DC treatment, the 1- and 2-year survival rates were significantly prolonged ${ }^{[25]}$. DC can be injected into the tumors directly. Nakamoto et al. ${ }^{[52]}$ enrolled 10 patients to receive autologous DC infusion into tumors following TACE. DC could be detected in the tumors for up to 17 days when the DCs were labelled with ${ }^{111}$ Indium. Tumor antigen-specific lymphocytes could be found around the tumors. However, no clinical benefit was found in this study.

\section{Checkpoint inhibitor immunotherapy}

Activation of naïve T-cells by DC is through ligation of $\mathrm{MHC}$ class $\mathrm{I} / \mathrm{II}$ and T-cell receptor (signal 1) and costimulatory molecular pathways (signal 2). Costimulatory molecular pathways may deliver positive or negative signals to T-cells and result in T-cell activation or T-cell anergy to specific antigens. In immunotherapy of cancer, checkpoint inhibitors can block negative costimulatory molecular pathways and enhance T-cell-mediated immunity. Clinically, checkpoint inhibitor immunotherapy already has obtained promising results in treating advanced melanoma. Tremelimumab, a blockade of cytotoxic T-cell antigen 4 (CTLA-4), was used to treat hepatitis C patients with $\mathrm{HCC}$ in a clinical tria|[53]. Twenty patients were enrolled and 17 patients were available to assess therapeutic responses. Partial response rate was $17.6 \%$, stable disease was $76.4 \%$, and time to progression was 6.48 months. Nivolumab, anti- 
programmed cell death protein-1, is another checkpoint inhibitor employed in a clinical trial of HCC treatment. In total, 262 patients were enrolled in dose-escalation and dose-expansion phases. The objective response rate was $20 \%$. Complete response rate was $1 \%$, partial response was $18 \%$, and stable disease was $45 \%$. The median progression-free survival was 4 months ${ }^{[54]}$. Currently, several clinical trials of checkpoint inhibitor immunotherapy are ongoing. Results will be published in the near future.

\section{T-cell immunotherapy}

T-cells are direct effector cells to attract cancer cells. Activated T-cells can be applied to treat cancers ${ }^{[55]}$. Takayama et al. ${ }^{[56]}$ conducted a randomized clinical trial by infusion of T-cells to prevent HCC recurrence after curative resection of HCC. One hundred and fifty patients were enrolled and randomized: 76 received adoptive immunotherapy with activated T-cells, and 74 patients received no adjuvant treatment. Autologous lymphocytes were activated by recombinant IL-2 and anti-CD3 antibody and could be expanded more than 1000 -fold. Compared to control, the frequency of tumor recurrence was decreased by $18 \%$, and time to the first tumor recurrence was longer. However, overall survival was not significantly affected.

Jiang et al. ${ }^{[57]}$ conducted a phase I trial using autologous tumor-infiltrating lymphocytes (TIL) to prevent tumor recurrence after curative resection for HCC. TIL was obtained from adjacent-tumor tissue and could be expanded by IL-2 and anti-CD3 in 15 of 17 patients. When the expanded TIL was infused back into the patients, only grade 1 flu-like symptoms and malaise were noted. After a median follow-up of 14 months, 12 patients were tumor-free and 3 patients had tumor recurrence. Basically, immunotherapy with expanded autologous TIL was safe and the toxicity was low. Future clinical trials may be conducted by the authors.

\section{Cytokine-induced killer cell therapy}

Autologous cytokine-induced killer (CIK) cells were also used to provide cell-mediated immunotherapy for HCC. Shi et al. ${ }^{[58]}$ conducted a phase I clinical trial using ClK cells to treat $\mathrm{HCC}$. CIK cells were expanded from PBMC ex vivo by interferon- $\gamma$ in the first day and followed by anti-CD3, IL-1 $\alpha$, and IL-2. After CIK cells were infused, the populations of $\mathrm{CD} 8^{+}$cells and DCs were both increased. Tumor volume was decreased in 3 of 13 patients. The authors concluded that infusion of CIK cells was safe and immunological status could be improved. Since CIK cells might show anti-tumor activity for $\mathrm{HCC}$, Hao et al ${ }^{[59]}$ conducted a randomized trial to compare the treatment efficacy of combination of TACE and CIK cells infusion vs. TACE alone for unresectable HCC. They enrolled 72 patients treated by combination of TACE and CIK cells infusion and 74 patient treated by TACE alone. The results showed progression-free survival and overall survival were both improved. The 1- and 2-year survival were $71.9 \%$ and $62.4 \%$ for combination therapy of TACE and CIK cells infusion, compared to $42.8 \%$ and $18.8 \%$ for therapy with TACE alone. Su et al. ${ }^{[60]}$ collected 7 randomized controlled trials and one controlled clinical trial to perform a meta-analysis study of comparison between $\mathrm{DC}+\mathrm{ClK}$ cells + TACE/RFA treatment for HCC and control. A total of 349 patients had DC + CIK cells + TACE/RFA treatment, compared to 344 patients as control. The results showed that DC + CIK cells + TACE/ RFA treatment improved 1- and 2-year overall survival.

\section{Tumor neo-antigens}

A successful DC-based immunotherapy for cancers needs specific tumor-associated antigens to promote anti-cancer immunity. HCC-associated antigens were well reviewed by Hong and Huang ${ }^{[61]}$ and Sun et al. ${ }^{[62]}$. Among the reported antigens, $\alpha$-fetoprotein, glypican-3 (GPC3), and multidrug resistance-associated protein-3 (MRP-3) were frequently expressed on $\mathrm{HCC}$ and were employed as tumor antigens to conduct clinical trials. However, the clinical responses were not satisfactory. Recently, Aref et al. ${ }^{[63]}$ found HCA519/TPX2 was an $\mathrm{HCC}$-associated antigen. When DCs were pulsed with this peptide, cytotoxic T-cells could be activated. Zhu et al. ${ }^{[64]}$ found the levels of cytokeratin (CK) 10 in $\mathrm{HCC}$ cell lines were higher than in normal liver tissue. CK 10 is a potentially targetable tumor-associated antigen. Whether these antigens can be presented by $D C$ to enhance anti-cancer immunity needs to be proved by clinical trials.

\section{CONCLUSION}

$\mathrm{HCC}$ is an aggressive cancer and can recur even when tumors are completely removed. Effective treatments for advanced stage HCC are still lacking. Cell-mediated immunotherapy is an attractive therapy for HCC with few toxicities. However, tumor response rates are only around $20 \%$ because immunosuppressive factors or cells interfere with the effects of immunotherapy. The combination of increasing immunity and depleting immunosuppressive factors shows promise for future success in conducting cell-mediated immunotherapy for HCC.

\section{DECLARATIONS}

\section{Authors' contributions}

W.C. Lee contributed solely to the paper.

\section{Financial support and sponsorship}

None. 


\section{Conflicts of interest}

There are no conflicts of interest.

\section{Patient consent}

Not applicable.

\section{Ethics approval}

Not applicable.

\section{REFERENCES}

1. Ferenci P, Fried M, Labrecque D, Bruix J, Sherman M, Omata M, Heathcote J, Piratsivuth T, Kew M, Otegbayo JA, Zheng SS, Sarin S, Hamid SS, Modawi SB, Fleig W, Fedail S, Thomson A, Khan A, Malfertheiner P, Lau G, Carillo FJ, Krabshuis J, Le Mair A; World Gastroenterology Organization. Hepatocellular carcinoma (HCC): a global perspective. J Clin Gastroenterol 2010;44:239-45.

2. Mazzaferro V, Regalia E, Doci R, Andreola S, Pulvirenti A, Bozzetti F, Montalto F, Ammatuna M, Morabito A, Gennari L. Liver transplantation for the treatment of small hepatocellularcarcinomas in patients with cirrhosis. N Engl J Med 1996;334:693-9.

3. Yao FY, Ferrell L, Bass NM, Watson JJ, Bacchetti P, Venook A, Ascher NL, Roberts JP. Liver transplantation for hepatocellular carcinoma: expansion of the tumor size limits does not adversely impact survival. Hepatology 2001;33:1394-403.

4. Lee WC, Lee CF, Cheng CH, Wu TJ, Chou HS, Wu TH, Soong RS, Chan KM, Yu MC, Chen MF. Outcomes of liver resection for hepatocellular carcinoma in liver transplantation era. Eur J Surg Oncol 2015;41:1144-52.

5. Meza-Junco J, Montano-Loza AJ, Liu DM, Sawyer MB, Bain VG, Ma M, Owen R. Locoregional radiological treatment for hepatocellular carcinoma; which, when and how? Cancer Treat Rev 2012;38:54-62.

6. Ray CE Jr, Haskal ZJ, Geschwind JF, Funaki BS. The use of transarterial chemoembolization in the treatment of unresectable hepatocellular carcinoma: a response to the Cochrane Collaboration review of 2011. J Vasc Interv Radiol 2011;22:1693-6.

7. Raoul JL, Sangro B, Forner A, Mazzaferro V, Piscaglia F, Bolondi L, Lencioni R. Evolving strategies for the management of intermediatestage hepatocellular carcinoma: available evidence and expert opinion on the use of transarterial chemoembolization. Cancer Treat Rev 2011;37:212-20.

8. Cheng AL, Kang YK, Chen Z, Tsao CJ, Qin S, Kim JS, Luo R, Feng J, Ye S, Yang TS, Xu J, Sun Y, Liang H, Liu J, Wang J, Tak WY, Pan H, Burock K, Zou J, Voliotis D, Guan Z. Efficacy and safety of sorafenib in patients in the Asia-Pacific region with advanced hepatocellular carcinoma: a phase III randomised, double-blind, placebo-controlled trial. Lancet Oncol 2009;10:25-34.

9. Kudo M. Molecular targeted therapy for hepatocellular carcinoma: bench to bedside. Dig Dis 2011;29:273-7.

10. Ling TC, Kang JI, Bush DA, Slater JD, Yang GY. Proton therapy for hepatocellular carcinoma. Chin J Cancer Res 2012;24:367-73.

11. Ishikawa T. Chemotherapy with enteric-coated tegafur/uracil for advanced hepatocellular carcinoma. World $J$ Gastroenterol 2008;14:2797-801.

12. Forner A, Reig ME, de Lope CR, Bruix J. Current strategy for staging and treatment: the BCLC update and future prospects. Semin Liver Dis 2010;30:61-74.

13. Kurkjian C, Kummar S, Murgo AJ. DNA methylation: its role in cancer development and therapy. Curr Probl Cancer 2008;32:187235.

14. Palucka K, Banchereau J. Dendritic-cell-based therapeutic cancer vaccines. Immunity 2013;39:38-48.

15. Lotze MT. Getting to the source: dendritic cells as therapeutic reagents for the treatment of patients with cancer. Ann Surg 1997;226:1-5.

16. Gabrilovich DI, Ciernik IF, Carbone DP. Dendritic cells in antitumor immune responses. I. Defective antigen presentation in tumor-bearing hosts. Cell Immunol 1996;170:101-10.

17. Tarte K, Klein B. Dendritic cell-based vaccine: a promising approach for cancer immunotherapy. Leukemia 1999;13:653-63.

18. Grabbe S, Beissert S, Schwarz T, Granstein RD. Dendritic cells as initiators of tumor immune responses: a possible of tumor immune strategy for tumor immunotherapy. Immunol Today 1995;16:117-21.

19. Hsu FJ, Benike C, Fagnoni F, Liles TM, Czerwinski D, Taidi B, Engleman EG, Levy R. Vaccination of patients with B-cell lymphoma using autologous antigen-pulsed dendritic cells. Nat Med 1996;2:528 .

20. Nestle FO, Alijagic S, Gilliet M, Sun Y, Grabbe S, Dummer R, Burg $\mathrm{G}$, Schadendorf D. Vaccination of melanoma patients with peptide- or tumor lysate-pulsed dendritic cells. Nat Med 1998;4:328-32.

21. Höltl L, Rieser C, Papesh C, Ramoner R, Bartsch G, Thurnher M. CD83+ blood dendritic cells as a vaccine for immunotherapy of metastatic renal-cell cancer. Lancet 1998;352:1358.

22. Di Lorenzo G, Buonerba C, Kantoff PW. Immunotherapy for the treatment of prostate cancer. Nat Rev Clin Oncol 2011;8:551-61.

23. Bauer C, Dauer M, Saraj S, Schnurr M, Bauernfeind F, Sterzik A, Junkmann J, Jakl V, Kiefl R, Oduncu F, Emmerich B, Mayr D, Mussack T, Bruns C, Rüttinger D, Conrad C, Jauch KW, Endres S, Eigler A. Dendritic cell-based vaccination of patients with advanced pancreatic carcinoma: results of a pilot study. Cancer Immunol Immunother 2011;60:1097-107.

24. Tarte K, Klein B. Dendritic cell-based vaccine: a promising approach for cancer immunotherapy. Leukemia 1999;13:653-63.

25. Lee WC, Wang HC, Hung CF, Huang PF, Lia CR, Chen MF Vaccination of advanced hepatocellular carcinoma patients with tumor lysate-pulsed dendritic cells: a clinical trial. $J$ Immunither 2005;28:496-504

26. Wang HY, Wang RF. Regulatory $\mathrm{T}$ cells and cancer. Curr Opin Immunol 2007;19:217-23.

27. Lee WC, Wu TJ, Chou HS, Yu MC, Hsu PY, Hsu HY, Wang CC. The impact of $\mathrm{CD} 4+\mathrm{CD} 25+\mathrm{T}$ cells in the tumor microenvironment of hepatocellular carcinoma. Surgery 2012;151:213-22.

28. Vignali DA, Collison LW, Workman CJ. How regulatory T cells work. Nat Rev Immunol 2008;8:523-32.

29. Huang CH, Hou YC, Pai MH, Yeh CL, Yeh SL. Dietary omega-6/ omega-3 polyunsaturated fatty acid ratios affect the homeostasis of $\mathrm{Th} /$ Treg cells in mice with dextran sulfate sodium-induced colitis. JPEN J Parenter Enteral Nutr 2017;41:647-56.

30. Chen X, Du Y, Lin X, Qian Y, Zhou T, Huang Z. CD4+CD25+ regulatory $\mathrm{T}$ cells in tumor immunity. Int Immunopharmacol 2016;34:244-9.

31. Kindlund B, Sjöling Å, Yakkala C, Adamsson J, Janzon A, Hansson LE, Hermansson M, Janson P, Winqvist O, Lundin SB. CD4+ regulatory T cells in gastric cancer mucosa are proliferating and express high levels of IL-10 but little TGF-beta. Gastric Cancer 2017;20:116-25.

32. Shen LS, Wang J, Shen DF, Yuan XL, Dong P, Li MX, Xue J, Zhang FM, Ge HL, Xu D. CD4(+)CD25(+)CD127(low/-) regulatory T cells express Foxp3 and suppress effector T cell proliferation and contribute to gastric cancers progression. Clin Immunol 2009;131:109-18.

33. Xu T, Duan Q, Wang G, Hu B. CD4 + CD25high regulatory T cell numbers and FOXP3 mRNA expression in patients with advanced esophageal cancer before and after chemotherapy. Cell Biochem Biophys 2011;61:389-92.

34. Kim S, Lee A, Lim W, Park S, Cho MS, Koo H, Moon BI, Sung SH Zonal difference and prognostic significance of foxp3 regulatory $\mathrm{T}$ cell infiltration in breast cancer. J Breast Cancer 2014;17:8-17. 
35. O'Callaghan DS, Rexhepaj E, Gately K, Coate L, Delaney D, O’Donnell DM, Kay E, O’Connell F, Gallagher WM, O'Byrne KJ. Tumour islet Foxp3+ T-cell infiltration predicts poor outcome in nonsmall cell lung cancer. Eur Respir J 2015;46:1762-72.

36. Lee WC, Wu TJ, Chou HS, Yu MC, Hsu PY, Hsu HY, Wang CC. The impact of CD4+ CD25+ T cells in the tumor microenvironment of hepatocellular carcinoma. Surgery 2012;151:213-22.

37. Gabrilovich DI, Bronte V, Chen SH, Colombo MP, Ochoa A, OstrandRosenberg S, Schreiber H. The terminology issue for myeloid-derived suppressor cells. Cancer Res 2007;67:425; author reply 426.

38. Movahedi K, Guilliams M, Van den Bossche J, Van den Bergh R, Gysemans C, Beschin A, De Baetselier P, Van Ginderachter JA. Identification of discrete tumor-induced myeloid-derived suppressor cell subpopulations with distinct $\mathrm{T}$ cell-suppressive activity. Blood 2008;111:4233-44

39. Peranzoni E, Zilio S, Marigo I, Dolcetti L, Zanovello P, Mandruzzato $\mathrm{S}$, Bronte V. Myeloid-derived suppressor cell heterogeneity and subset definition. Curr Opin Immunol 2010;22:238-44.

40. Ueha S, Shand FH, Matsushima K. Myeloid cell population dynamics in healthy and tumor-bearing mice. Int Immunopharmacol 2011;11:783-8.

41. Ko JS, Rayman P, Ireland J, Swaidani S, Li G, Bunting KD, Rini B, Finke JH, Cohen PA. Direct and differential suppression of myeloidderived suppressor cell subsets by sunitinib is compartmentally constrained. Cancer Res 2010;70:3526-36.

42. Ozao-Choy J, Ma G, Kao J, Wang GX, Meseck M, Sung M, Schwartz M, Divino CM, Pan PY, Chen SH. The novel role of tyrosine kinase inhibitor in the reversal of immune suppression and modulation of tumor microenvironment for immune-based cancer therapies. Cancer Res 2009;69:2514-22.

43. Daurkin I, Eruslanov E, Vieweg J, Kusmartsev S. Generation of antigen-presenting cells from tumor-infiltrated CD11b myeloid cells with DNA demethylating agent 5-aza-2'-deoxycytidine. Cancer Immunol Immunother 2010;59:697-706.

44. Gabrilovich DI. Combination of chemotherapy and immunotherapy for cancer: a paradigm revisited. Lancet Oncol 2007;8:2-3.

45. Kusmartsev S, Cheng F, Yu B, Nefedova Y, Sotomayor E, Lush R, Gabrilovich D. All-trans-retinoic acid eliminates immature myeloid cells from tumor-bearing mice and improves the effect of vaccination. Cancer Res 2003;63:4441-9.

46. De Santo C, Serafini P, Marigo I, Dolcetti L, Bolla M, Del Soldato P, Melani C, Guiducci C, Colombo MP, Iezzi M, Musiani P, Zanovello P, Bronte V. Nitroaspirin corrects immune dysfunction in tumor-bearing hosts and promotes tumor eradication by cancer vaccination. Proc Natl Acad Sci U S A 2005;102:4185-90.

47. Suzuki E, Kapoor V, Jassar AS, Kaiser LR, Albelda SM. Gemcitabine selectively eliminates splenic Gr-1+/CD11b+ myeloid suppressor cells in tumor-bearing animals and enhances antitumor immune activity. Clin Cancer Res 2005;11:6713-21.

48. Mirza N, Fishman M, Fricke I, Dunn M, Neuger AM, Frost TJ, Lush RM, Antonia S, Gabrilovich DI. All-trans-retinoic acid improves differentiation of myeloid cells and immune response in cancer patients. Cancer Res 2006;66:9299-307.

49. Iwashita Y, Tahara K, Goto S, Sasaki A, Kai S, Seike M, Chen CL, Kawano K, Kitano S. A phase I study of autologous dendritic cellbased immunotherapy for patients with unresectable primary liver cancer. Cancer Immunol Immunother 2003;52:155-61.

50. Palmer DH, Midgley RS, Mirza N, Torr EE, Ahmed F, Steele JC, Steven NM, Kerr DJ, Young LS, Adams DH. A phase II study of adoptive immunotherapy using dendritic cells pulsed with tumor lysate in patients with hepatocellular carcinoma. Hepatology 2009;49:124-32.

51. Qiu Y, Xu MB, Yun MM, Wang YZ, Zhang RM, Meng XK, Ou-Yang $\mathrm{XH}$, Yun S. Hepatocellular carcinoma-specific immunotherapy with synthesized alpha1,3- galactosyl epitope-pulsed dendritic cells and cytokine-induced killer cells. World J Gastroenterol 2011;17:5260-6.

52. Nakamoto Y, Mizukoshi E, Tsuji H, Sakai Y, Kitahara M, Arai K, Yamashita T, Yokoyama K, Mukaida N, Matsushima K, Matsui O, Kaneko S. Combined therapy of transcatheter hepatic arterial embolization with intratumoral dendritic cell infusion for hepatocellular carcinoma: clinical safety. Clin Exp Immunol 2007; 147:296-305.

53. Sangro B, Gomez-Martin C, de la Mata M, Iñarrairaegui M, Garralda E, Barrera P, Riezu-Boj JI, Larrea E, Alfaro C, Sarobe P, Lasarte JJ, Pérez-Gracia JL, Melero I, Prieto J. A clinical trial of CTLA4 blockade with tremelimumab in patients with hepatocellular carcinoma and chronic hepatitis C. J Hepatol 2013;59:81-8.

54. El-Khoueiry AB, Sangro B, Yau T, Crocenzi TS, Kudo M, Hsu C, Kim TY, Choo SP, Trojan J, Welling TH Rd, Meyer T, Kang YK, Yeo W, Chopra A, Anderson J, Dela Cruz C, Lang L, Neely J, Tang H, Dastani HB, Melero I. Nivolumab in patients with advanced hepatocellular carcinoma (CheckMate 040): an open-label, non-comparative, phase 1/2 dose escalation and expansion trial. Lancet 2017;389:2492-502.

55. Brenner MK, Heslop HE. Adoptive T cell therapy of cancer. Curr Opin Immunol 2010;22:251-7.

56. Takayama T, Sekine T, Makuuchi M, Yamasaki S, Kosuge T, Yamamoto J, Shimada K, Sakamoto M, Hirohashi S, Ohashi Y, Kakizoe T. Adoptive immunotherapy to lower postsurgical recurrence rates of hepatocellular carcinoma: a randomised trial. Lancet 2000;356:802-7.

57. Jiang SS, Tang Y, Zhang YJ, Weng DS, Zhou ZG, Pan K, Pan QZ, Wang QJ, Liu Q, He J, Zhao JJ, Li J, Chen MS, Chang AE, Li Q, Xia JC. A phase I clinical trial utilizing autologous tumorinfiltratinglymphocytes in patients with primary hepatocellular carcinoma. Oncotarget 2015;6:41339-49.

58. Shi M, Bing Zhang, Tang ZR, Lei ZY, Wang HF, Feng YY, Fan ZP, $\mathrm{Xu}$ DP, Wang FS. Autologous cytokine-induced killer cell therapy in clinical trial phaseI is safe in patients with primary hepatocellular carcinoma. World J Gastroenterol 2004;10:1146-51.

59. Hao M, Lin H, Chen Q, Ye YB, Chen QZ, Chen MS. Efficacy of transcatheter arterial chemoembolizationcombined with cytokineinduced killer cell therapy onhepatocellular carcinoma: a comparative study. Chin J Cancer 2010;29:172-7.

60. Su Y, Yang Y, Ma Y, Zhang Y, Rao W, Yang G, Kou C. The efficacy and safety of dendritic cells co-cultured with cytokine-induced killer cell therapy in combination with TACE-predominant minimallyinvasive treatment for hepatocellular carcinoma: a meta-analysis. Clin Lab 2016;62:599-608.

61. Hong Y, Huang J. Autoantibodies against tumor-associated antigens for detection of hepatocellular carcinoma. World J Hepatol 2015;7:15815.

62. Sun Z, Zhu Y, Xia J, Sawakami T, Kokudo N, Zhang N. Status of and prospects for cancer vaccines against hepatocellular carcinoma in clinical trials. Biosci Trends 2016;10:85-91.

63. Aref AM, Hoa NT, Ge L, Agrawal A, Dacosta-Iyer M, Lambrecht N, Ouyang Y, Cornforth AN, Jadus MR. HCA519/TPX2: a potential T-cell tumor-associated antigen for human hepatocellular carcinoma. Onco Targets Ther 2014;7:1061-70.

64. Zhu Z, Liu Z, Liu Y, Wang C, Li R, Liu H, Gu B, Li G, Zhang S. Screening and identification of the tumor-associated antigen CK10, a novel potential liver cancer marker. FEBS Open Bio 2017;7:627-35. 